\title{
Dampak Pandemi Covid-19 terhadap Kinerja Universitas Advent Indonesia (UNAI)
}

\author{
Albinur Limbong \\ Fakultas Teknologi Informasi, Universitas Advent Indonesia \\ e-mail: alimbong@unai.edu
}

\begin{abstract}
Abstrak
Pandemi covid-19 telah melanda Indonesia bahkan seluruh dunia sejak awal tahun 2020, dan banyak manusia telah menderita penyakit akibat pandemic ini dan bahkan tidak sedikit manusia yang telah meninggal. Disamping membunuh begitu banyak manusia, pandemic covid-19 telah menjadi mimpi buruk bagi banyak orang yang hidup di dunia sekarang ini, telah menghancurkan perekonomian, bahkan setiap aspek kehidupan kita, termasuk dunia pendidikan. Pemerintah Indonesia telah menerapkan regulasi lockdown untuk menghambat atau memutus rantai penyebaran covid-19, dimana orang diharuskan bekerja dari rumah. Tidak terkecuali, UNAI secara tiba-tiba harus mengubah proses belajar mengajar dari tatap muka di kelas (offline) menjadi daring (online), sekalipun UNAI adalah perguruan tinggi berasrama dimana mahasiswa harus tinggal di asrama. Sehubungan dengan perubahan yang tiba-tiba dari proses belajar mengajar ini, tentu ini akan berdampak pada prestasi belajar mahasiswa, kinerja dosen maupun institusi. Adalah menarik untuk mempelajari apakah pandemi covid-19 membawa dampak negative saja kepada UNAI atau apakah ada dampak positifnya. Tujuan dari studi ini adalah untuk melihat apakah pandemi covid-19 berdampak pada kinerja mahasiswa, dosen dan UNAI sebagai institusi. Kinerja mahasiswa dilihat dari indeks prestasi semester (IPS) mahasiswa, sementara kinerja dosen dilihat dari evaluasi dosen oleh mahasiswa dan kinerja publikasi hasil penelitian. Kinerja UNAI secara institusi, selain kinerja mahasiswa dan dosen, juga dilihat kinerja keuangan, rangking, akreditasi dan lain-lain. Studi ini dilakukan sejak Maret 2020 hingga Juni 2021. Hasil studi menunjukkan bahwa pandemic covid-19 berdampak positif pada pencapaian mahasiswa, karena ada peningkatan rerata IPS yang cukup signifikan dari 3,21 menjadi 3,26. Namun dari segi evaluasi dosen oleh mahasiswa ada sedikit penurunan, walau tidak signifikan, dari 4,41 menjadi 4,39. Persentasi dosen yang menghasilkan publikasi buku maupun artikel ilmiah di jurnal yang diakui meningkat dari sekitar $40 \%$ (sebelum pandemi) menjadi $55 \%$ (pada saat pandemi). Secara institusi, UNAI menunjukkan kinerja yang bahkan lebih baik pada masa pandemi covid-19, dilihat rangking UNAI menurut badan perangkingan dunia (webometrics), akreditasi, dan indikator keuangan (working capital, liquidity and cash). Dapat disimpulkan bahwa, sekalipun ada sisi negatifnya, pandemi covid-19 telah membawa dampak positif kepada UNAI. Pandemi Covid-19 adalah seperti berkat di tengah musibah (blessing in disguise) bagi UNAI.
\end{abstract}

Kata Kunci: Pandemi Covid-19, kinerja, mahasiswa, dosen, UNAI

\section{The Impact of Covid-19 Pandemic to Universitas Advent Indonesia (UNAI) Performance}

\begin{abstract}
Covid-19 pandemic has hit Indonesia or even the world since early 2020 Indonesia, and many people have suffered from the disease due to the pandemic and even some of them have died. Besides killing so many people, Covid-19 pandemic has been a night mare for many people living in this world, it has been destroying our economics, or even every aspect of our life, including education. Indonesian government has applied a lock down regulation, where people must work from home. No exception, UNAI has to change
\end{abstract}


from offline teaching to become online teaching, although UNAI is a dormitory school. Due to the sudden change in teaching and learning processes, there should be an impact to student achievement, faculty performance or even UNAI as an institution. It is interesting to see whether the covid-19 pandemic brings negative effects or are there any positive effects. The purpose of this study is to see whether covid-19 pandemic influence student, teacher or even UNAI's performance. The performance of student is seen by the GPA (Grade Point Average), while the teacher performance is seen by teacher evaluation and the performance in research and publications. The parameters of UNAI performance involve students and teachers' performance, besides other institutional indicator, such as financial, ranking and accreditation, etc. The study was carried out since March 2020 until June 2021. The results of the study show that the covid-19 pandemic brought a positive impact in the academic achievement of UNAI students, since there was a significant increase in GPA from 3.21 to 3.26. However, in terms of student evaluation on teacher performance there was a slight decrease 4.413 to 4.386, although the decrease was not significant. The percentage of teacher published in a recognized journal and book publication increased from around $40 \%$ (before pandemic) to 55\% (during pandemic). Institutionally, UNAI performed even better during pandemic, in terms of webometrics world ranking, accreditation, and financial indicators (working capital, liquidity and cash). In conclusion, regardless its negative sides, the covid-19 pandemic has brought a positive impact to UNAI. Covid-19 pandemic is like a blessing in disguise to UNAI.

Keywords: Covid-19 Pandemic, Student, Teacher, UNAI, Performance

\section{Pendahuluan}

Pandemi covid-19 terjadi di Indonesia mulai awal 2020, dan khususnya untuk dunia pendidikan dampak pandemi covid-19 semakin terasa sejak awal Maret 2020 dimana pemerintah Indonesia membuat kebijakan pembelajaran secara daring untuk semua tingkat pendidikan termasuk perguruan tinggi. Pembelajaran daring dan pandemi covid-19 membawa dampak kepada dunia pendidikan [1-4] apakah positif maupun negatif. Pada penelitian terdahulu $[5,6]$ telah dilaporkan hasil penelitian tentang dampak pandemi covid-19 terhadap kinerja mahasiswa [5] dan Dosen [6] pada tahun akademik 2019/2020. Pandemi covid-19 berdampak positif terhadap kinerja mahasiswa dilihat dari indeks prestasi semester (IPS) yang didapat mahasiswa, namun untuk kinerja dosen, dilihat dari evaluasi dosen oleh mahasiswa sedikit menurun walau penurunan tersebut tidak signifikan.

Dampak pandemi covid-19 terhadap IPS mahasiswa maupun kinerja dosen adalah pengaruh jangka pendek, atau hanya sekitar 3 bulan atau setengah semester masa pandemi. Adalah menarik untuk melihat dampak jangka panjang (lebih dari satu tahun) dari pandemi covid-19 terhadap kinerja mahasiswa maupun dosen. Di samping kinerja dosen dan mahasiswa menarik juga untuk melihat untuk meneliti tentang dampak pandemi covid-19 terhadap institusi, misalnya kinerja keuangan, rangking perguruan tinggi, akreditasi, kinerja penelitian, dan lain-lain.

Tujuan dari penelitian ini adalah untuk melihat dampak pandemi covid-19 setelah lebih dari satu tahun terhadap prestasi belajar mahasiswa, kinerja dosen, dan kinerja institusi (keuangan, rangking, akreditasi, dan lain-lain).

\section{Metode Penelitian}

Penelitian ini dilakukan di Universitas Advent Indonesia selama masa pandemi covid-19 sejak Maret 2020 hingga Juni 2021. Populasi untuk penelitian ini adalah Dosen yang bekerja dan mahasiswa UNAI yang mendaftar pada tahun 2019/2020 dan 2020/2021. Data evaluasi dosen dan indeks prestasi semester mahasiswa untuk tahun 2019/2020 dan 2020/2021 diunduh dari sistem online informasi nilai yang dimiliki oleh kantor Biro Administrasi Akademik UNAI dan Kantor Wakil Rektor 1 Bidang Akademik [7]. Data keuangan adalah data yang diterima dari kantor keuangan UNAI, dimana kecuali data tahun 2020/2021, semua data sudah hasil audit dari auditor yang diakui. Data rangking perguruan tinggi diperoleh dari dari 
situs web lembaga pemeringkat tersebut, demikian hal-halnya dengan data-data lain diperoleh secara online dari lembaga yang bersangkutan. Data dianalisis dengan statistik deskriptif, dengan mengambil rerata, dan membandingkan rerata dengan uji statistik yang relevan.

\section{Hasil dan Pembahasan}

\section{Dampak Pandemi Covid-19 Terhadap Kinerja Mahasiswa}

Pada studi sebelumnya [5] diteliti pengaruh pandemi covid-19 terhadap prestasi belajar mahasiswa (indeks prestasi semester mahasiswa) pada tahun 2019/2020. Pengaruh pandemi covid-19 terhadap prestasi belajar dalam studi tersebut adalah pengaruh sekitar 3 bulan (setengah semester genap 2019/2020). Hasil yang didapat adalah secara umum ada peningkatan rerata IPS mahasiswa UNAI meningkat pada semester genap (masa pandemi covid-19) dibanding IPS semester ganjil (sebelum pandemi). Walau secara umum ada peningkatan, namun pandemi Covid-19 membawa dampak negatif hanya pada mahasiswa tahun pertama (baru) saja, sedangkan pada tingkat 2, 3 dan senior pandemi covid19 justru membawa dampak yang sedikit positif. Ada kenaikan yang signifikan IPS mahasiswa baik pria maupun wanita peningkatan pria sedikit lebih baik $(2,5 \%)$ dari wanita $(1,2 \%)$, artinya pria lebih cepat beradaptasi dengan pembelajaran daring dibanding wanita.

Sebagaimana disarankan dalam penelitian tersebut, dimana perlu dilihat dampak dari pandemi covid19 setelah lebih dari tahun, yaitu hingga tahun 2020/2021. Pada tabel 1 diberikan rerata Indeks Prestasi Semester mahasiswa selama dua tahun 2019/2020 (setengah semester pandemi) dan 2020/2021 (satu tahun penuh pandemi).

Tabel 1 Indeks prestasi semester mahasiswa berdasarkan fakultas tahun 2019/2020 dan 2020/2021.

\begin{tabular}{|r|l|r|r|r|r|r|r|}
\hline \multirow{2}{*}{ No } & \multirow{2}{*}{ Fakultas } & \multicolumn{3}{c|}{$\mathbf{2 0 1 9 / 2 0 2 0}$} & \multicolumn{3}{c|}{$\mathbf{2 0 2 0 / 2 0 2 1}$} \\
\cline { 3 - 8 } & & Ganjil & Genap & Rerata & Ganjil & Genap & Rerata \\
\hline 1 & Ekonomi & 3,21 & 3,15 & 3.18 & 3,30 & 3,39 & 3,34 \\
\hline 2 & Ilmu Keperawatan & 3,18 & 3,20 & 3.19 & 3,25 & 3,41 & 3,33 \\
\hline 3 & KIP & 3,21 & 3,10 & 3.15 & 3,04 & 3,01 & 3,03 \\
\hline 4 & Filsafat & 3,07 & 3,31 & 3.19 & 3,22 & 3,37 & 3,29 \\
\hline 5 & MIPA & 3,41 & 3,47 & 3.44 & 3,18 & 3,38 & 3,28 \\
\hline 6 & Teknologi Informasi & 3,30 & 3,19 & 3.11 & 3,30 & 3,27 & 3,28 \\
\hline & UNAI & 3,19 & 3,24 & 3.21 & 3,22 & 3,30 & 3,26 \\
\hline
\end{tabular}

Dapat dilihat pada tabel bahwa ada peningkatan rerata IPS pada tahun 2020/2021 (rerata IPS 3,26) dibanding 2019/2020 (rerata IPS 3,21), sama seperti hasil studi pada tahun 2019/2020. Peningkatan ini terlihat hampir di semua fakultas, kecuali fakultas MIPA dan Keguruan dan Ilmu Pendidikan (KIP). Fakta ini menunjukkan bahwa ada kendala dalam pembelajaran daring di dua fakultas MIPA dan KIP atau bidang studi untuk dua fakultas ini belum berhasil mengatasi kendala pembelajaran daring akibat pandemi covid19. Namun perlu dipertanyakan apakah peningkatan IPS mahasiswa adalah juga peningkatan kompetensi akademik mahasiswa atau karena keterbatasan dosen untuk membuat soal ujian atau mengembangkan sistem pengawasan ujian yang dapat mencegah mahasiswa untuk menyontek atau bekerja sama dengan orang lain.

\section{Dampak Pandemi Covid-19 Terhadap Kinerja Dosen}

Pada artikel sebelumnya [6] telah dilaporkan pengaruh pandemi covid-19 terhadap kinerja dosen pada tahun 2019/2020. Kinerja dosen adalah hasil evaluasi dosen oleh mahasiswa UNAI. Pengaruh pandemi covid-19 terhadap kinerja dosen dalam studi tersebut adalah pengaruh sekitar 3 bulan (setengah semester genap 2019/2020), didapati bahwa kinerja dosen sedikit menurun pada masa pandemi covid-19, walau penurunan tersebut tidak signifikan. 
Hal-hal lain yang didapat berhubungan dengan kinerja dosen yang diakibatkan oleh pandemi covid19 adalah:

1. Ada perbedaan rerata kinerja dosen dari satu fakultas ke fakultas lain, namun perbedaan tersebut bukan diakibatkan oleh pandemi itu sendiri, karena hal tersebut juga diamati bahkan sebelum masa pandemi.

2. Tidak ada perbedaan yang signifikan rerata kinerja dosen menurut jenis kelamin, antara laki-laki dan perempuan.

3. Tidak ada perbedaan yang signifikan rerata kinerja dosen menurut jenjang pendidikan dosen, antara yang berpendidikan magister dengan yang berpendidikan doktor (S3).

4. Tidak ada perbedaan yang signifikan rerata kinerja dosen menurut usia, antara dosen milenial (yang berusia kurang atau sama dengan 40 tahun) dengan dosen yang bukan milenial (usia di atas 40 tahun).

Pada tabel 2 diberikan data hasil evaluasi dosen oleh mahasiswa untuk 2 tahun ajaran, 2019/2020 dan 2020/2021. Dilihat dari tabel 2 bahwa rerata evaluasi dosen oleh mahasiswa untuk tahun 2020/2021 mengalami sedikit peningkatan dibanding evaluasi dosen tahun 2019/2020, walau peningkatan tersebut tidak signifikan. Data ini semakin memperkuat hasil sebelumnya bahwa tidak ada pengaruh pandemi covid19 terhadap evaluasi dosen kinerja dosen menurut mahasiswa.

Tabel 2 Rerata evaluasi dosen menurut fakultas selama 4 semester.

\begin{tabular}{|l|r|r|r|r|r|r|}
\hline \multirow{2}{*}{ Fakultas } & \multicolumn{3}{|c|}{$\mathbf{2 0 1 9 / 2 0 2 0}$} & \multicolumn{3}{c|}{$\mathbf{2 0 2 0 / 2 0 2 1}$} \\
\cline { 2 - 7 } & Ganjil & Genap & Rerata & Ganjil & Genap & Rerata \\
\hline Ekonomi & 88,81 & 88,50 & 88,65 & 87,01 & 88,93 & 87,97 \\
\hline Filsafat & 89,27 & 86,40 & 87,83 & 89,07 & 90,14 & 89,61 \\
\hline Keperawatan & 92,35 & 90,98 & 91,67 & 90,08 & 90,64 & 90,36 \\
\hline FKIP & 82,12 & 83,89 & 83,01 & 83,75 & 86,14 & 84,94 \\
\hline MIPA & 89,35 & 86,36 & 87,85 & 88,84 & 85,80 & 87,32 \\
\hline IT & 83,65 & 86,12 & 84,88 & 85,98 & 84,56 & 85,27 \\
\hline UNAI & 87,59 & 87,04 & 87,32 & 87,46 & 87,70 & 87,58 \\
\hline
\end{tabular}

Dalam studi ini juga didapat hasil berikut:

1. Ada perbedaan rerata kinerja dosen menurut mahasiswa dari satu fakultas ke fakulas lain, walau perbedaan itu bukan akibat pandemi.

2. Tidak ada perbedaan yang signifikan rerata kinerja dosen menurut mahasiswa berdasarkan jenis kelamin, antara laki-laki dan perempuan.

3. Tidak ada perbedaan yang signifikan rerata kinerja dosen menurut mahasiswa berdasarkan jenjang pendidikan dosen, antara yang berpendidikan magister dengan yang berpendidikan doktor (S3).

4. Tidak ada perbedaan yang signifikan rerata kinerja dosen menurut mahasiswa berdasarkan usia dosen, antara yang milenial dengan yang bukan milenial.

\section{Dampak Pandemi Covid-19 Terhadap Kinerja Keuangan}

Kinerja keuangan suatu organisasi, termasuk lembaga pendidikan tinggi seperti UNAI, adalah working capital, liquidity dan persentase Account Receivable (AR) terhadap pendapatan (income). Pada tabel 3 diberikan data working capital, liquidity dan rasion AR to income. Universitas Advent Indonesia adalah perguruan tinggi di bawah naungan Gereja Masehi Advent Hari Ketujuh (GMAHK). Secara finansial Yayasan UNAI mengelola dana sendiri yang diperoleh dari uang kuliah mahasiswa dan usaha-usaha yang ada kampus, di samping ada bantuan dari pemilik GMAHK, walau bantuan tersebut tidak signifikan. Karena di bawah organisasi GMAHK, maka UNAI memiliki misi yang sejalan dengan misi gereja, yaitu untuk menyelamatkan jiwa-jiwa, membentuk karakter, dan mendidik mahasiswa sekalipun ada yang tidak mampu 
secara ekonomi. Karena alasan-alasan di atas, maka hutang mahasiswa (account receivable) cukup signifikan dibanding penerimaan.

Tabel 3 Data indikator keuangan UNAI selama 5 tahun, termasuk 1 tahun penuh pandemi covid-19 $(2020 / 2021)$

\begin{tabular}{|l|c|c|c|c|c|}
\hline Indikator*/Tahun & $\mathbf{2 0 1 6 / 2 0 1 7}$ & $\mathbf{2 0 1 7 / 2 0 1 8}$ & $\mathbf{2 0 1 8 / 2 0 1 9}$ & $\mathbf{2 0 1 9 / 2 0 2 0}$ & $\mathbf{2 0 2 0 / 2 0 2 1}$ \\
\hline Working Capital (\%) & $111 \%$ & $85 \%$ & $102 \%$ & $124 \%$ & $164 \%$ \\
\hline Liquidity (\%) & $187 \%$ & $160 \%$ & $160 \%$ & $166 \%$ & $209 \%$ \\
\hline \%AR to income & $14 \%$ & $9 \%$ & $10 \%$ & $14 \%$ & $11 \%$ \\
\hline
\end{tabular}

Tahun 2016-2019 adalah 3 tahun anggaran sebelum masa pandemi covid-19. Pada tahun anggaran 2019/2020 pandemi covid-19 sudah terjadi selama 4 bulan (Maret s/d Juni 2020). Sedangkan tahun 2020/2021 adalah masa covid-19 selama satu tahun penuh. Dapat dilihat dari tabel 3 bahwa sebelum pandemi (2016-2019) rerata working capital adalah 99,3\% lebih rendah dibanding tahun 2019/2020 sebesar $124 \%$ atau tahun 2020/2021 sebesar 164\%. Ini berarti ada peningkatan working capital selama masa pandemi covid-19.

Ditinjau dari segi ketersediaan dana cair (liquidity), sebelum pandemi covid-19 rerata dana cair atau likuiditas adalah sebesar 169\%, pada masa 4 bulan pandemi 2019/2020 likuiditas sedikit berkurang menjadi $166 \%$, dan masa pandemi penuh sepanjang tahun 2020/2021 likuiditas menjadi 209\%. Ini berarti ada peningkatan likuiditas pada masa pandemi. Dilihat dari segi rasio hutang mahasiswa terhadap pendapatan, maka rerata rasio hutang mahasiswa sebelum pandemi adalah $11 \%$, angka bertambah pada tahun 2019/2020, namun kembali dapat ditekan menjadi 11\% pada tahun 2020/2021. Dilihat dari 3 indikator utama keuangan, dapat disimpulkan bahwa pandemi covid-19 tidak berdampak buruk terhadap kinerja keuangan UNAI, dan bahkan ada peningkatan dari segi working capital dan likuiditas.

Sebenarnya pendapatan UNAI drastis berkurang karena mahasiswa tidak tinggal di asrama, dan ada penurunan jumlah mahasiswa, ditambah lagi ada kebijakan pemberian potongan dan beasiswa akibat pandemi covid-19. Penurunan pendapatan tersebut diatasi dengan membuat berbagai kebijakan penghematan anggaran antara lain mengurangi biaya operasional seperti biaya kafetaria, listrik, air, perjalanan, capital expenditure dan biaya lain-lain. Menarik untuk menganalisis hubungan antara hasil evaluasi dosen (ED) dengan IPS mahasiswa. Untuk menghitung koefisien korelasi antara ED dan IPS digunakan rumus korelasi peringkat (rank) Spearmen [8]. Rangking ED adalah urutan besarnya skor evaluasi dosen, rangking IPS adalah urutan besarnya IPS mahasiswa menurut fakultas.

Tabel 4 Data rerata evaluasi dosen (ED) dan rerata indeks prestasi semester mahasiswa (IPS) untuk menentukan koefisien korelasi antara ED dan IPS.

\begin{tabular}{|l|c|c|c|c|}
\hline Fakultas & Rerata ED & Rerata IPS & Rangking ED & Rangking IPS \\
\hline Ekonomi & 87,97 & 3,34 & 3 & 1 \\
\hline Filsafat & 89,61 & 3,29 & 2 & 3 \\
\hline Keperawatan & 90,36 & 3,33 & 1 & 2 \\
\hline KIP & 84,94 & 3,03 & 6 & 4,5 \\
\hline MIPA & 87,32 & 3,28 & 4 & 4,5 \\
\hline IT & 85,27 & 3,28 & 5 & \\
\hline
\end{tabular}

Dengan menggunakan korelasi peringkat (rank) Spearmen berhubungan dengan data pada tabel 4 di atas didapat koefisien korelasi antara rerata ED dan Rerata IPS sebesar 0,81. Ini berarti bahwa korelasi antara hasil yang diperoleh mahasiswa (IPS) dengan penilaian mahasiswa terhadap dosen (ED) adalah kuat atau tinggi. Kepuasan mahasiswa terhadap pembelajaran yang dilakukan dosen berkorelasi kuat terhadap hasil belajar mahasiswa, atau penilaian mahasiswa terhadap kinerja dosen berhubungan kuat dengan pencapaian mahasiswa. 


\section{Dampak Pandemi Covid-19 Terhadap Kinerja Lain}

\section{Learning Management System}

Berkat lain yang UNAI dapat pada masa pandemi, selain yang sudah dijelaskan di atas, adalah bahwa UNAI mendapatkan peringkat tujuh dari 5877 perguruan tinggi di Indonesia yang menggunakan Learning Management System (LMS) pada bulan Februari 2021 (lihat gambar 1). Kementerian Pendidikan dan Kebudayaan RI mengembangkan sistem laporan penggunaan LMS untuk semua perguruan tinggi di Indonesia. Pada masa pandemi 2020-2021, UNAI telah melakukan berbagai terobosan untuk menggunakan LMS berbasis Moodle, mengembangkan sistem sarana dan prasarana jaringan, sistem informasi dan server LMS, dan membuat pelatihan kepada dosen untuk menggunakan moodle dan pembelajaran daring melalui Zoom. Dalam waktu singkat mayoritas dosen UNAI telah mampu menggunakan sistem pembelajaran online yang dikembangkan.

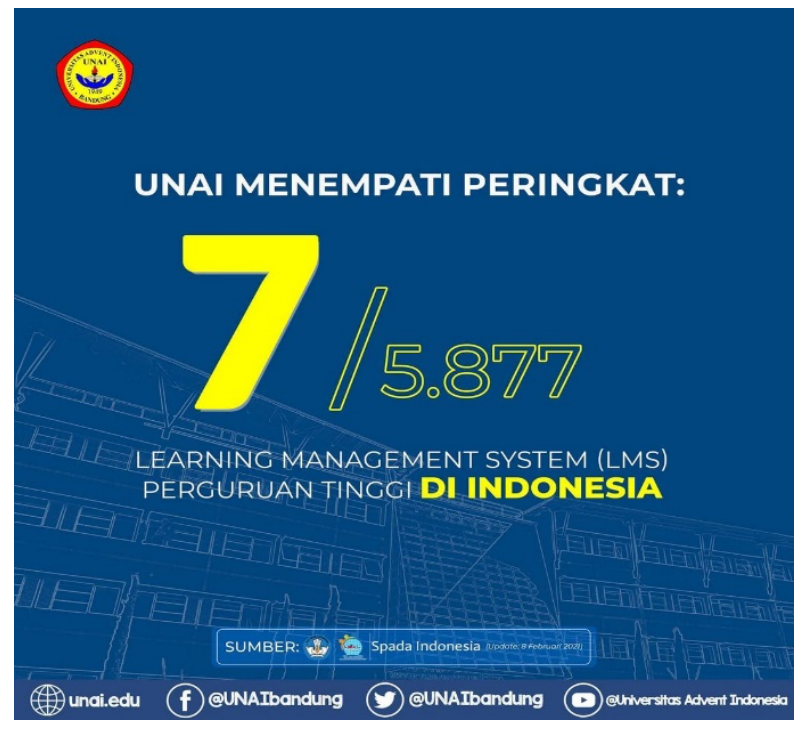

Gambar 1 Pemeringkatan UNAI pada SPADA Indonesia [9]

\section{Ranking UNAI Dari Webometric}

Salah satu berkat besar yang UNAI alami dalam masa pandemi covid-19 adalah peningkatan dalam rangking perguruan tinggi menurut Webometrics. Pemeringkatan menurut Webometrics didasarkan atas parameter: impact, openness dan excellence. Pada gambar 2 diberikan hasil capture dari situs rangking UNAI menurut webometrics [10]. Dapat dilihat bahwa rangking UNAI secara nasional adalah 235, sedangkan secara internasional adalah 8746 sebagaimana terdapat di Gambar 2.

Peringkat UNAI dari sumber yang sama selama 4 tahun terakhir diberikan pada tabel 5 . Peringkat UNAI pada tahun 2021 ini meningkat cukup tajam dibandingkan 5 tahun sebelumnya. Ini membuktikan bahwa UNAI telah berupaya dan berhasil mengembangkan system pembelajaran online, dan memiliki impact, openness dan excellence yang semakin baik yang dibaca oleh Webometrics dari situs web UNAI. Ini adalah salah satu berkat lain yang UNAI capai akibat pandemi covid-19. 


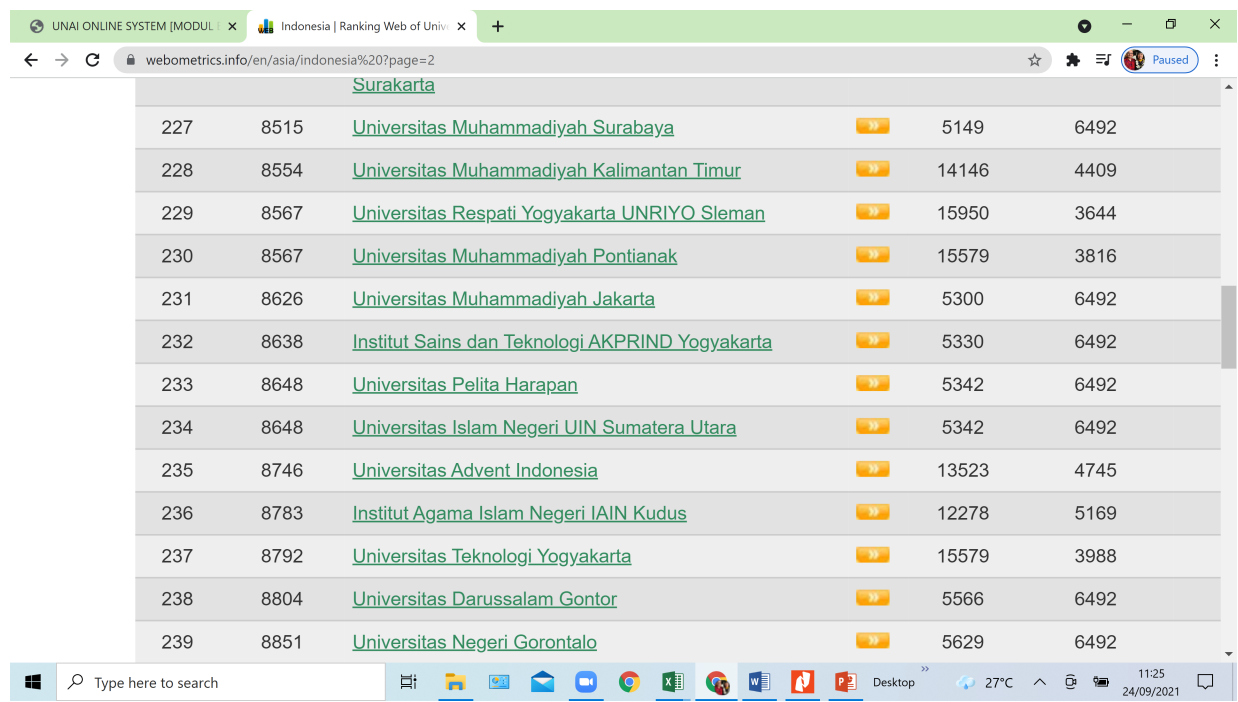

Gambar 2 Peringkat UNAI dan PT lain di Indonesia menurut Webometrics pada bulan Agustus 2021 [10]

Jika dibandingkan dengan 17 perguruan tinggi Advent yang ada di kawasan Asia Pasifik Selatan, khususnya 4 perguruan tinggi terbesar di kawasan ini (UNAI dan UNKLAB di Indonesia, AIIAS dan AUP di Filipina dan AIU di Thailand), maka untuk pertama kali UNAI menduduki peringkat pertama menurut Webometrics (lihat tabel 6). Selama bertahun-tahun terakhir UNAI selalu berada di peringkat kedua, di bawah AIIAS.

Tabel 5 Peringkat UNAI menurut Webometrics selama 4 tahun terakhir

\begin{tabular}{|l|l|l|l|l|}
\hline PT & $\mathbf{2 0 1 8}$ & $\mathbf{2 0 1 9}$ & $\mathbf{2 0 2 0}$ & $\mathbf{2 0 2 1}$ \\
\hline UNAI & 305 & 312 & 292 & 235 \\
\hline
\end{tabular}

Tabel 6 Peringkat 4 Perguruan Tinggi Advent terbesar di kawasan Asia Pasifik Selatan. UNAI= Universitas Advent Indonesia, AIIAS= Adventist International Institute of Advance Studies, AUP=Adventist University of the Phillipines, AIU=Asia-Pacific International University, UNKLAB= Universitas Klabat.

\begin{tabular}{|l|l|l|}
\hline PT & Dunia & Nasional \\
\hline UNAI & 8746 & 235 \\
\hline AIIAS & 11495 & 51 \\
\hline AUP & 14123 & 72 \\
\hline AIU & 14494 & 118 \\
\hline UNKLAB & 16540 & 584 \\
\hline
\end{tabular}

Visi UNAI pada tahun 2025 adalah menjadi Universitas yang unggul dalam bidang Pengajaran, Penelitian dan Pengabdian kepada Masyarakat berdasarkan Falsafah Pendidikan Advent di kawasan Asia Pasifik Selatan. Dengan melihat fakta di atas, dapat diyakini bahwa UNAI telah mencapai visinya bahkan lebih cepat dari tahun yang direncanakan yaitu 2025.

\section{Akreditasi dari BAN-PT}

Akreditasi program studi dan Universitas adalah salah satu yang terus ditingkatkan oleh UNAI baik oleh Badan Akreditasi Nasional Perguruan Tinggi (BAN-PT) di bawah DIKTI Kemendikbud RI, maupun oleh AAA (Adventist Acrrediting Association) di bawah GMAHK yang berpusat di Amerika Serikat. UNAI memiliki 14 program studi yang mayoritas sudah terakreditasi B dari Badan Akreditasi Nasional Perguruan Tinggi (BAN-PT), demikian halnya secara institusi UNAI sudah terakreditasi B. Pada masa pandemi ini ada 6 
program studi yang diakreditasi ulang oleh BAN-PT, semuanya mendapat hasil "sangat baik", artinya hasilnya akreditasi sebelum dapat dipertahankan. Memang tidak terjadi peningkatan akreditasi dari BANPT karena ada kendala dalam peningkatan drastis kinerja outputs dan outcomes dengan borang yang baru dengan 9 standar. Akreditasi dari AAA berhasil diperpanjang dengan peringkat akreditasi yang sama. Ini tentu saja adalah berkat besar bagi UNAI, dimana mendapat pengakuan secara nasional maupun internasional tanpa mengeluarkan sedikit pun dana untuk proses reakreditasi.

\section{Kinerja lain-lain}

Dengan membuat kebijakan untuk peningkatan kinerja penelitian dan pengabdian pada masyarakat, sekalipun dana terbatas akibat menurunnya pendapatan, dimana dosen akan menerima bantuan berupa insentif bila telah berhasil menerbitkan hasil penelitiannya baik di jurnal Nasional, terindeks SINTA maupun Scopus, dan menerbitkan buku dengan mendapat sertifikat Hak Kekayaan Intelektual (HKI) maka persentasi dosen yang melakukan publikasi meningkat pada tahun $2020 / 2021$, dari rerata $40 \%$ dari tahun sebelumnya menjadi 55\% pada tahun 2020/2021. Kembali ini adalah berkat besar bagi UNAI dalam masa pandemi covid-19.

Sekalipun sulit dilakukan, karena mahasiswa tidak berada di kampus UNAI, dan interaksi dengan dosen hanyalah secara online, namun mahasiswa UNAI tetap berupaya mengikuti berbagai kompetisi secara nasional dan berhasil mendapatkan penghargaan untuk bidang lomba debat Bahasa Inggris, dan kompetisi lainnya.

\section{Kesimpulan dan Saran}

Dari hasil penelitian di atas disimpulkan bahwa sekalipun pandemi covid-19 berdampak secara social dan ekonomi kepada masyarakat dan bangsa secara umum namun ada beberapa hal positif yang UNAI bisa dapatkan pada masa pandemi covid-19, antara lain:

1. Kinerja mahasiswa dari segi indeks prestasi semester tetap mengalami peningkatan pada masa pandemi covid-19 selama satu tahun penuh 2020/2021, walau ada penurunan pada fakultas tertentu.

2. Tidak ada perbedaan yang signifikan pada kinerja dosen menurut mahasiswa antara sebelum dan sesudah pandemi covid-19. Tidak ada perbedaan kinerja dosen menurut jenis kelamin, usia, dan jenjang pendidikan dosen.

3. Kinerja keuangan UNAI secara working capital dan liquiditas semakin meningkat. Working capital meningkat dari rata-rata 4 tahun sebelumnya (2016-2020) 106\% menjadi $164 \%$ pada tahun 2020/2021. Demikian halnya dengan liquidity meningkat dari rata-rata 4 tahun sebelumnya $168 \%$ menjadi $209 \%$. Di samping working capital dan liquidity yang semakin baik, rasio antara account receivable mahasiswa terhadap income menunjukkan kinerja sedikit lebih baik, dimana menurun dari rata-rata 4 tahun sebelumnya $12 \%$ menjadi $11 \%$ pada masa pandemi covid- 19 .

4. Peringkat UNAI dalam hal penerapan Learning Management System (LMS) sangat mengagumkan yaitu peringkat 7 dari 5.877 perguruan tinggi di Indonesia pada bulan Februari 2021.

5. Peringkat UNAI menurut Webometrics meningkat cukup signifikan dari tahun-tahun sebelumnya menjadi peringkat 235 secara nasional atau 8746 secara internasional. Bahkan UNAI telah berhasil mencapai visinya menjadi yang terbaik di antara 17 perguruan tinggi Advent di kawasan Asia Pasifik Selatan.

6. Persentase dosen yang melakukan publikasi ilmiah dan buku meningkat dari tahun sebelumnya $40 \%$ menjadi 55\% tahun 2020/2021.

7. Akreditasi UNAI dapat dipertahankan, baik menurut BAN-PT maupun AAA.

Namun, Perlu dilakukan kajian mendalam terhadap peningkatan IPS mahasiswa selama masa pandemi covid-19. Apakah peningkatan tersebut berkorelasi dengan peningkatan kompetensi akademik mahasiswa tersebut atau hanya karena keterbatasan dosen dalam pengawasan saat ujian yang dapat mencegah mahasiswa untuk menyontek atau bekerja sama dengan orang lain. Salah satu cara untuk membuktikan 
ini adalah dengan melihat kinerja mahasiswa nantinya setelah tamat atau pada saat bekerja, apakah kompetensinya baik atau tidak.

\section{Referensi}

[1] Ali Sadikin. A. dkk., Pembelajaran Daring di Tengah Wabah Covid-19, BIODIK: Jurnal Ilmiah Pendidikan Biologi, vol. 6(2), 2020.

[2] Wijaya, R. dkk., Dampak pandemi Covid19 terhadap pemanfaatan e-learning, Dimensi, 9(2), 2020.

[3] Pratiwi, E.W., Dampak Covid-19 terhadap kegiatan pembelajaran online di sebuah Perguruan Tinggi Kristen di Indonesia, Perspektif Ilmu Pendidikan, vol. 34(1), 2020.

[4] Kusnayat, A., Pengaruh Teknologi Pembelajaran Kuliah Online di era Covid-19 dan dampaknya terhadap mental mahasiswa, Edukasi dan Teknologi Pembelajaran, vol. 1(2), 2020.

[5] Limbong, A, Pengaruh Model Pembelajaran Daring Akibat Pandemi Covid-19 Terhadap Prestasi Belajar Mahasiswa UNAI pada Semester Genap 2019/2020, Teika, vol. 10(2), 2020.

[6] Limbong, A, Dampak Pandemi Covid-19 Terhadap Kinerja Dosen UNAI Pada Tahun Ajaran 2019/2020, Teika, vol. 11(10), 2021.

[7] Universitas Advent Indonesia, http://online2.unai.edu/pr1/welcome.php, data diunduh pada sekitar bulan Agustus 2020 dan Juli 2021.

[8] Limbong, A., dkk., Statistika Bidang Teknologi Informasi, Yayasan Kita Menulis, 2021.

[9] Dikti Depdikbud, https://spada.kemdikbud.go.id/, data diunduh Februari 2021

[10] Webometris, https://www.webometrics.info/en/asia/indonesia\%20?page=2, data diunduh Agustus 2021. 